\title{
STRATEGY OF OPTIMALIZATION CASH WAQF IN INDONESIA
}

\section{STRATEGI OPTIMALISASI WAKAF TUNAI DI INDONESIA}

\author{
P.S. Nadya1a; F.A. Alwyni2; P. Hadiyati³; M. Iqbal ${ }^{4}$ \\ 1aStudy Program of Sharia Economics, Faculty of Economics and Business, Perbanas \\ Institute, Jl. Perbanas, Karet Kuningan-Jakarta Selatan, \\ e-mail: prameswara.samofa@perbanas.id \\ 2Study Program of Sharia Economics, Faculty of Economics and Business, Perbanas \\ Institute, Jl. Perbanas, Karet Kuningan-Jakarta Selatan, \\ e-mail: Falwyni@gmail.com \\ ${ }^{3}$ Study Program of Sharia Economics, Faculty of Economics and Business, Perbanas \\ Institute, Jl. Perbanas, Karet Kuningan-Jakarta Selatan, \\ e-mail: puji.hadayati@perbanas.id \\ 4Study Program of Sharia Economics, Faculty of Economics and Business, Perbanas \\ Institute, Jl. Perbanas, Karet Kuningan-Jakarta Selatan, \\ e-mail: iqbal@perbanas.id
}

\begin{abstract}
This study aims to identify various problems of cash waqf management in Indonesia. Identification of these various problems is expected to be formulated by various alternative solutions. Based on the research, it was identified that there were three main obstacles in the process of optimizing cash waqf, namely socialization, regulations and Nazhir, all of which were broken down in several sub-problems. The solutions that can be offered from these three constraints are socialization programs, both on understanding and cash waqf mechanisms, improving existing cash waqf regulations, specifically on the role of BWI and funding for the development of cash waqf, as well as programs designed to improve capacity asset management for Nazhir. Based on this solution, the strategy that can be carried out is more comprehensive and coordinated socialization, making regulations that can optimize the role of BWI and also optimize funds for the development of cash waqf, and continuous improvement of Nazhir's competency.
\end{abstract}

Keywords: Cash Waqf, Socialization, Regulation, Nazhir, Solution

\begin{abstract}
ABSTRAK
Penelitian ini bertujuan untuk mengidentifikasi beragam masalah dari manajemen wakaf tunai di Indonesia. Identifikasi permasalahan ini diharapkan dapat menghasilkan formulasi alternatif solusi permasalahan yang dihadapi. Berdasarkan hasil penelitian, berhasil teridentifikasi dalam tiga pokok bahasan yaitu kendala dalam proses optimasi
\end{abstract}


wakaf uang, sosialisasi, regulasi dan nazir yang selanjutnya diturunkan menjadi beberapa sub permasalahan. Solusi yang ditawarkan terkait dengan tiga permasalahan pokok adalah program sosialisasi, pemahaman dan mekanisme wakaf tunai, mendorong adanya aturan tentang wakaf tunai, terutama tentang peran BWI dan pendanaan untuk pengembangan wakaf tunai, progran peningkatan kapasitas manajemen aset bagi nazir. Berdasarkan solusi yang ditawarkan, strategi yang dapat diterapkan adalah sosialisasi dilakukan lebih menyeluruh dan terkoordinasi, membuat regulasi atau aturan yang dapat mengoptimalkan peran BWI dan juga mengoptimalkan pendanaan untuk pengembangan wakaf tunai dan peningkatan atau pengembangan kompetensi nazir yang berkelanjutan.

Kata Kunci: Wakaf Tunai, Sosialisasi, Regulasi, Nazir, Solusi

Nadya, Prameswara Samofa. 2018. Strategy of Optimalization Cash Waqf In Indonesia. Jurnal Syarikah 4 (2): 108-121.

\section{INTRODUCTIONS}

Data collected by the Indonesian Waqf Agency (Badan Wakaf Indonesia = BWI) shows that the land of waqf area throughout Indonesia reached 4,359,443,170 m2 spread across 435,768 locations throughout Indonesia. The management of vacant waqf land can be useful for the benefit of the people, therefore another waqf instrument is needed, namely cash waqf. Cash waqf is more flexible than land waqf. Apart from the large amount of assets represented, all people who have money but do not own land can also participate. So almost all circles of society can participate without any limitations having to own a piece of land and be limited to the rich.

Optimalization of cash waqf will increase the economy of a country. Empty waqf land can be managed productively such as for schools, hospitals, plantations, livestock, community facilities and infrastructure that can also provide employment for the community. According to Rahman (2009) Waqf plays a role in developing the economy of a country, not only in physical development but also in the development of the quality of the people's self that has an important role in the country's development.

Based on BWI's data, until December 31, 2015 Nazhirof cash waqf registered in BWI amounted to 102 and 15 of them are Islamic Financial Institution Recipient of Cash Waqf (Lembaga Keuangan Syariah Penerima Wakaf Uang = LKS-PWU) throughout Indonesia. The government has responded positively to the potential of cash waqf because the Government knows cash waqf can increase Indonesia's development. On 11 May 2002 MUI issued a fatwa concerning the permissibility of cash waqf (waqf annuqūd), provided that the principal value of waqf must be guaranteed of its sustainability, in accordance with the words of the Prophet Muhammad: 
"hold the principal and give the yield." (Hadith of Muslim)

Issued of of the Law of the Republic of Indonesia No. 41 of 2004 concerning Waqf, is actually directed to empower waqf so that it becomes an instrument in constructing the socio-economic life of Muslims. President Susilo Bambang Yudhoyono on January 8, 2010 launched a national movement for cash waqf (Gerakan Wakaf Tunai) and according to him in an effort to socialize cash waqf to the community needed contributions from all parties involved.

The existence of all supporting aspects in the implementation of cash waqf, that is land, community, cash waqf fund raising institutions, management institutions and government support, should the potential of cash waqf in Indonesia be maximally utilized However, optimizing cash waqf in Indonesia still does not look real. The development of cash waqf in Indonesia is far behind compared to other countries such as Egypt, KSA, Turkey, Malaysia and Singapore. Indonesia has a truly complete aspect to be able to optimize cash waqf in Indonesia, including abundant natural resources, large populations, LKS-PWU, Nazhir and Government Regulations.

From previous research, it was known that the problems surrounding waqf ranged from the understanding of society, regulation and Nazhir. For this reason, it is necessary to classify problems and similar solutions and make a priority scale of the problems and solutions that exist.

\section{LITERATURE REVIEW AND RESEARCH METHODS}

Etimological, waqf means al-Habs'an at-Tasharrafthat is keep the utilization.In the fatwa of the Indonesian Ulama Council (Majelis Ulama Indonesia = MUI), it was explained that cash waqf or cash waqf is an endowment by a person, group of people, institution or legal entity in the form of cash.

Cash waqf has long been practiced in various countries such as Malaysia, Bangladesh, Egypt, Kuwait and other Islamic countries in the Middle East. In Indonesia, on 11 May 2002 MUI issued a fatwa concerning the permissibility of cash waqf (waqf al-nuqūd), provided that the principal value of waqf must be guaranteed of its sustainability.

Research of Huda, Anggraini, Rini, Hudori, \& Mardoni (2014) said thatthe priority of the waqf management problem lies in the waqf who surrenders the waqf property directly to the person rather than through the waqf management agency. The solution to the problem of waqf management is to increase Nazhir's incentives and intensive training for Nazhir. The solution is to improve the accountability of waqf management, so that professionalism in the management of waqf is formed and increases the trust of public.

Furqon (2011) found three main things in the practice of representing money in sharia financial institutions. First, it is necessary to raise funds that require socialization through cash waqf brochures. Second, the mechanism for the representation of money in LKS does not have a special unit that serves prospective waqif who want to represent 
cash, waqif is served by customer service officers. And third, investment in the real sector, by allocating cash waqf funds collected for the construction of the Mother and Child Hospital (RSIA). In addition, investment in the financial sector, by depositing cash waqf funds in BSM Current Account and invested in Syariah Mandiri Deposits.

Muntaqo (2015) tried to analyze the problems and prospects of waqf in Indonesia, especially after the issued of Law No. 40 of 2004 concerning Endowments. Problems that occur include the lack of socialization of waqf fiqh and the waqf management law regulations, the lack of Nazir's commitment, the weakness of the institutional supervision system and funding problems. With the issued of Law No. 40 of 2004 concerning endowments strengthens the prospect of waqf in Indonesian representative institutions, such as people's thinking can be more progressive about productive waqf, strengthening waqf institutions nationally, structuring administration of waqf management that is organized and law enforcement of representatives.

Adeyemi et al. (2016) measured the level of public awareness in representation and knowing the factors that cause limited cash waqf in Malaysia. The results showed that the level of public awareness in representing cash is still low and the factors that influence the limited cash waqf in Malaysia include social culture, lack of socialization, and lack of understanding.

Md Saad, Kassim, \& Hamid (2013) explained that Malaysian Waqf An-Nur Berhad, IIUM Endowment Fund and one waqf institution in Singapore namely the
Majlis Ugama Islam Singapore, adopted a structured approach in financing the development of waqf property by managing and invest waqf assets. They have created opportunities to improve waqf institutions and revitalize the potential of waqf assets to generate greater profits for the community.

Dahlan (2015) revealed that Nazhir's perception was influenced by access to information media and understanding of the regulation regarding cash waqf, besides Nazhir's educational background also affected Nazhir's perception in order to become a professional Nazhir.

\section{Research methods}

This study uses qualitative research design, that is research that intends to understand the phenomenon of what is experienced by the subject of research such as behavior, perceptions, motivations, actions, etc., in a holistic manner and by way of descriptions in the form of words and language, at a special natural context and by utilizing various natural methods.

The data collection usesin-depth interview techniques to build the model at the beginning of work. The results of the interview will be used to build a model that will later be useful for making a research questionnaire that will be disseminated to experts who have previously been interviewed.

By limiting specific research locations to waqf practices in Indonesia, this study uses the marketing mix as a hypothesis to detect problems that cause disruption of waqf optimization. Interviews were carried out not only to uncover the actual problems that occurred, but also to find out the right 
solutions and strategies so that the management of waqf could be carried out optimally.

\section{RESEARCH RESULT AND DISCUSSION}

The interviews in this study were conducted on five respondents consisting of regulators, in this case serving as Indonesian Waqf Agency Commissioners (BWI), academics, who is lecturers who have done a lot of research in the field of endowments, as well as practitioners, who is managing director at Nazhir institutions has carried out representative activities in a professional manner, namely. Dr. Imam Nur Azis, Dr. Nurul Huda, drg. Imam Rulyawan, M.Kes, Prof. Dr. Uswatun Hasanah and Dr. Imam Teguh Saptono.

Dr. Imam Nur Azis is a practitioner in the field of waqf and halal industries who have had international reputation. Through the Akrom Foundation, which he founded, he encouraged waqf in the regional scope. Currently he is Indonesia's representative in the Asean Mall Pattani project, a waqf-based regional project in Thailand. In addition to the regional region, he and Akrom Foundation also carried out waqf activities in several locations, such as the Machine Ship Wakaf program for tough Da'i in West Manggarai, East Nusa Tenggara and water waqf for a boarding school in Purwakarta, West Java. The field of endowments was increasingly cultivated when starting in 2017 he was appointed as a commissioner of BWI to take care of certification issues. The international network owned by a doctor in the field of development science was built when he became a practitioner in business development in several companies.

In waqf, reputation of Dr. Nurul Huda is widely recognized by being a BWI commissioner. At least for the past 5 years he has focused on the field of waqf, especially after completing a dissertation on the theme of zakat and waqf at Airlangga University. Starting his career as an academic since 1994, this man born in 1969 is a Sharia economic activist. At the Association of Islamic Economic Experts (IAEI) he served as Chair of the IX Section of the IAEI Central Board.

Widely known as a philanthropic activist, Drg. Imam Rulyawan, M.Kes is the President Director of Dompet Dhuafa Philanthropy since 2016. Indeed, he is a dentist who has a high social care spirit. In 2007, he was appointed as the Director of Free Health Services at Dompet Dhuafa and since then he has been involved in the world of philanthropy. On the other hand, these 98 activists have managerial abilities honed while active in various organizations, both in mosques, Indonesian Dentist Association (PDGI), hospitals and also various projects and business units of Dompet Dhuafa. Through the Tube Wakaf business unit which is still under the management of Dompet Dhuafa Philanthropy, he likes to socialize waqf in the community. One of them is waqf on behalf of Sandiaga Uno for 1 billion rupiah for OK Oce businessmen.

Someone with a big contribution in the world of waqf in Indonesia, he is Prof. Dr. Uswatun Hasanah. Beginning with a dissertation entitled 'The Role of Waqf in Realizing Social Welfare', until now he has produced approximately 126 scientific works, most of which are endowed with 
waqf. This expertise that made lecturers at the University of Indonesia and several other universities also became members of the team drafting a law on waqf which eventually resulted in Republic of Indonesia Act No. 41 of 2004 concerning endowments.

Started his career as a banker, Dr. Imam Teguh Saptono is now focusing on a field that is his passion, namely waqf, by serving as President Director of PT. Global Itqon Semesta (Global Waqf Corporation) which oversees more than 10 Nazhirs, with the achievement of making the first waqf business model. Still in the world of waqf, the lecturer of the Bogor Agricultural Institute (IPB) and the STIE Indonesia Banking School (IBS) are also believed to be waqf commissioners. While serving as President Director of PT BNI Syariah, his company innovated by becoming the first Sharia Bank to serve waqf with an integrated application and website platform.

Based on the interviews, all respondents stated that the most basic obstacle in managing cash waqf was the problem in the socialization activities that is the level of Indonesian society's literacy about waqf in general was still very minimal, especially if mentioned about cash waqf. The lack of literacy is caused by two things, namely beliefs and perceptions.

According to Prof. Dr. Uswatun Hasanah, the belief about God's promise that the treasure spent in the way of Allah will be replaced with something better is fundamental in the activities of waqf. And that belief has not been firmly planted in the minds of the Muslim community in Indonesia. Perceptively, there are still many who are aware or unconscious of believing that by inheriting their assets it will reduce their assets. Whereas in QS Al Baqarah (2): 261 it is stated that spending wealth in the way of Allah will be given multiple rewards like a seed that grows seven grains, in each one hundred seed grains.

The importance of this belief has an impact on several issues related to the constraints in optimizing cash waqf, that is, people are reluctant to represent due to the perception that the assets represented will reduce assets owned, supported by the reality that regulators are still running programs related to optimization waqf with less attention, seen from its development which tended to stagnate from year to year, even though in 2010 the Waqf Movement was launched. Altohough the belief about God's reply to those who spend their wealth in the way of Allah is also supported by promises of rewards for those who help these activities (helping the religion of God) God will certainly help and confirm their position, as Allah said in QS Muhammad (47): 7). In the academic field, not many academics research about waqf and seek solutions to the development of waqf in Indonesia, caused by ignorance of the essence of waqf for Muslims. Among waqf practitioners themselves encountered obstacles constraints Nazhir's professionalism, due to lack of confidence in the retribution obtained when working on his business seriously.

Perception is a person's interpretation of an object. In the context of optimizing cash waqf there are indications of constraints related to community perceptions that have been 
formed, firstly, the perceptions of the Indonesian people about the shape of the waqf object. The community has for generations believed that waqf is that waqf assets must be eternal, so the majority of waqf assets in Indonesia are in the form of land and buildings with allotments as mosques, prayer rooms, schools and funerals. Besides there is also a belief that waqf can only be used for socio-religious activities. In fact, in the time of the Prophet to the Caliphate of Islam, waqf was actually more productive. This can be seen from the history of the first waqf, where the land represented by Umar bin Khathab is productive plantation land. The results of the plantation are used for the benefit of the ummah and may also be used by Wakif. Similarly, during the Islamic Caliphate. For example, in the era of Saladin AlAyyubi's leadership, the use of stateowned land was used for plantations whose results could be enjoyed by the people of the country.

Likewise on cash waqf. Imam AzZuhri (died $124 \mathrm{H}$ ) states that it is recommended that waqf dinar and dirham be used for the development of Islamic, social and educational facilities. Cash waqf during the Ayyubi Dynasty was used to finance the country's development, as well as build mosques, schools, hospitals, and lodging places.

Second, perceptions about shifting values in waqf are already believed by the community where the value of waqf cannot be reduced. This belief actually does not have a strong footing, because in addition to the land itself, which is the majority waqf asset, it can be reduced in value due to changes in location values, also, according to Imam T. Saptono, there is a nature of cycles recognized by the Qur'an, as mentioned in verse Al Quran which tells of a dream that was anchored by Yusuf AS about the future of Egypt, where the usual 7 years will be replaced with a difficult 7 years (period of drought), then replaced again with periods of rain falling sufficiently (QS Yusuf (12): 47-49). The nature of the cycle is also mentioned in Surah Al-FAjr (89): 15-16 which says about human habits which when God tests them and glorifies and gives pleasure then says' My Lord has glorified me ', but when the test arrived by limiting his sustenance, he said' My Lord has insulted me '.

The two verses above explain the existence of a cycle in life, both the harvest and the drought, and when humans are glorified and when humans are limited in sustenance, it is a natural thing that happens in life. Likewise with assets that are deposited, can increase but can also be reduced naturally. This is in accordance with investment theory, where for investment where the yield opportunity is high, there is also a higher risk of loss than investment, where the yield opportunity is lower (high risk high return).

To overcome the problems surrounding the socialization of cash waqf, there are a number of things that have been done, among others through socialization programs carried out by BWI, including BWI Goes to Campus conducted in order to touch the millennial generation, Duta Wakaf Program, partnership cooperation, as BWI has done with Bank Indonesia (BI) in supporting Sharia economic development programs and with the United National Development Program (UNDP) in 
supporting Sustainable Development Goals, as well as data collection of waqf assets throughout Indonesia using technology, making it easy accessed.

Socialization activity by waqf practitioners are also carried out through personal and institutional approaches, both to individuals and institutions that have the potential to become wakif. The impact of the socialization is quite effective by opening the horizons of the prospective wakif so that they want to place their assets, either in the form of land, buildings or cash, into productive waqf assets.

In addition to the steps that have been taken, waqf in Indonesia also demands that various steps be taken in order to develop waqf, especially cash waqf in Indonesia. One thing that needs to be targeted is the planting of faith in the Indonesian Muslim community will reward Allah for the activities of spending wealth in the way of Allah. This, according to Prof. Dr. Uswatun Hasanah, is very important and fundamental for efforts to socialize waqf, especially cash waqf in Indonesia. The activities that can be carried out are through a comprehensive approach to ulama, da'ah and mubaligh so that they can broadcast about Islamic philanthropy, especially about waqf, to the Indonesian Muslim community. This effort should be quite effective considering that at this time there has been a resurgence of a high level of Islam among the people, it can be seen from the large public interest in attending lectures by contemporary scholars, both directly, and through online media.

Another thing that needs to be done is echoing the success stories of the existing cash waqf practices, so that they can be a good example, as well as promotion for the development of cash waqf, where the community does not hesitate to place their wealth in the interests of waqf development.

Stepping on the following problems, the results of the study also show constraints in the field of regulation. Since 2004, Act number 41 concerning waqf has been ratified by one of the considerations that waqf institutions have economic potential and benefits that need to be managed effectively and efficiently in the interests of worship and to promote public welfare. But in practice, there are still interests that have not been accommodated by the law.

Some of the things that are noted are first, the existing regulations have not accommodated the process of developing cash waqf. To carry out development in various sectors, regulations that are accommodative for these development activities are needed. No exception for cash waqf, regulations that are able to support the development of cash waqf are needed. At present, the existing law still does not support the management of cash waqf in Indonesia optimally, due to a number of things that have not been regulated by law.

Second, related to the LKS-PWU, further rules are still needed to improve the technical activities. At present there are 17 Sharia Banks that have been registered as LKS-PWU. But in reality, the number of Islamic Banks that are LKSPWU has not given significant results. This is due to the lack of seriousness of the Sharia Bank with its role as the LKSPWU. According to Dr. Nurul Huda, this seriousness is actually a natural thing, because Sharia Bank as a profit institution 
certainly has thoughts regarding benefits for its position as the LKS-PWU, which has not been touched at all with the existing regulations. Regulations need to be made that are more accommodating to the interests of the LKS-PWU so that it can be a stimulus for Islamic Banks to take part actively in the development of cash waqf in Indonesia.

Third, the problem of BWI's position and authority. At present, in practice on the BWI field there are constraints related to limited authority. Several sources acknowledged that BWI's authority over abandoned waqf assets was still limited. Indonesia does not adhere to the main nazir system, so BWI's authority only reaches the supervision of various waqf activities in Indonesia. As a result, BWI does not have the authority to handle waqf assets which are neglected due to the lack of Nazir's professionalism. Regarding Nazhir's professionalism will be discussed in the next sub-chapter.

In the arrangement of tasks between BWI and the Directorate of Waqf Empowerment of Ministry of Religion Empowerment, overlaps still occur. There is a realm that can be done by BWI and at the same time the Directorate of Waqf Empowerment of the Ministry of Religion, as well, there is a realm that is not done because of the unclear division of tasks between the two. For this reason, firmness is needed in the law regarding the division of tasks between the two bodies, so that the practice of implementing waqf development in Indonesia, especially cash waqf, can run more professionally.

Fourth, the problem of budget for BWI. BWI requires an adequate budget for the development of waqf, both for waqf outreach activities and operational activities. For example in operational activities is the cost of managing a waqf land certificate, where many occur after handing over the waqf land assets, wakif will be free from all matters involving the asset, including if the land has not been certified. At present, BWI's budget still comes from the Ministry of Religion budget in the form of operational assistance. The solution that can be taken is BWI is also given part of the percentage that is the right of Nazhir, the amount of which is a maximum of $10 \%$ of waqf assets.

Finally, the development of waqf in general is also hampered by land regulations in Indonesia, where Indonesia adheres to a law that does not separate ownership of land assets with building assets. As a result, a lot of waqf land in Indonesia is difficult to become productive assets. This is related to productive waqf management activities, where cash waqf is in the productive waqf realm.

For this reason, it is necessary to take a number of steps to improve the order of laws relating to cash waqf, including the revision of the Act of the Republic of Indonesia No. 41 of 2004 concerning Waqf in order to accommodate the need for the development of cash waqf, by listening to inputs regarding the implementation of cash waqf that have existed since the Law of the Republic of Indonesia No. 41 of 2004 concerning Waqf was enacted. Some things that need to be regulated further are related to BWI's role in developing waqf, especially cash waqf and division of tasks with the Ministry of Religion's Endowment Empowerment Directorate, 
as well as arrangements for funds that can be obtained by BWI in optimizing its role for waqf development in Indonesia, especially cash waqf.

For the sake of this interest, in fact BWI has attempted to initiate a new act to flesh out Republic of Indonesia Law No. 41 of 2004 concerning waqf to be more accommodating in implementing waqf activities, especially cash waqf. It is hoped that the drafting of the law can be implemented immediately so that regulations that favor the implementation of waqf development programs, especially cash waqf, in Indonesia can be immediately implemented.

In addition to these actions, regulations also need to be made to support or accelerate the development of waqf steps, especially cash waqf in Indonesia, such as government regulations, presidential regulations and so forth, so that implementers in the field can have definite guidelines for steps to develop waqf, especially cash waqf in the country.

In conducting regulations that support the development of cash waqf in Indonesia, it is also necessary to consider making BWI have a role as the parent nazhir, in which the parent Nazir has full authority to manage all waqf assets in a country. In practice, the main nazhir cannot work alone because it requires other nazhir roles, called Nazhir partners, so that waqf can be managed properly. Nazhir parent has a coordination function in the waqf management process to run well, and monitor it. So that the mainnazhir has the right to appoint Nazhir partners who will manage certain waqf assets and transfer them to others if
Nazhir partners cannot carry out the mandate properly.

In its history of the country, waqf has recorded a long history, which is in line with the development of Islam in Indonesia. Endowments are a complementary attribute of the efforts to spread Islam in the archipelago, where local people have inherited land for the purpose of building mosques. Thus, Nazhir has been around since Islam entered the archipelago. Usually Nazhir is a local religious leader.

In the modern era, along with the complexity of problems among Muslims, professionalism for Nazhir was demanded in managing waqf assets, both in the form of land, buildings and, moreover, money. In reality there are neglected or not well managed waqf assets as mandated by waqif, caused by nazhir who are not trustworthy, untrustable, do not have the capability to manage waqf assets and several other causes which essentially lead to nazhir's lack of professionalism.

Regulation in Indonesia, which is stated in Republic of Indonesia's Act Number 41 of 2004 concerning waqf, states that Nazhir can come from individuals or legal entities. In practice, legal entities are better able to manage waqf professionally, trustable and accountable.

Some of the breakthroughs that have been made by BWI in order to overcome the problem of the lack of Nazhir's ability in managing waqf assets are by making Nazhir associations. It is expected that with this association, communication between Nazhir will be formed which then impacts on the dialogue and discussion among Nazhir 
who can ultimately improve fair competitiveness between Nazhir. Another breakthrough that was made was the plan to create a Profession Certification Institute (Lembaga Sertifikasi Profesi = LSP), directly under BWI, which facilitated the certification process for all Nazir in Indonesia. It is hoped that Nazhir who has obtained a certificate can carry out their duties professionally. On the other hand, Nazhir certification will increase public confidence that the waqf assets entrusted (mauquf) will be well managed.

In addition, now there are movements carried out by several Zakat Amil Institutions (LAZ) that have previously had a lunge as LAZ which operates professionally as a nazhir waqf. In Indonesia the rules of zakat, including the management of amil, are more mature than the rules of representation, so that generally amil institutions have operated by upholding their professionalism.

Beside it, there are also some thoughts regarding Nazhir's professionalism. First, nazhir should not be an individual but an institution that has a clear legal entity, because legal entities are easier to be held accountable for the management of waqf assets that have been secured, so they can operate more professionally. In practice, in the field, professional Nazirs are from legal entities.

Second, it is proposed that Islamic banks can play a further role in developing cash waqf as Nazhir. At present Islamic Banks can only act as LKS-PWU, which means that they can only collect cash waqf and then channel it to Nazhir. However, actually Islamic Banks, with their usual banking functions, are institutions that have the ability to mobilize funds, which are certainly used to operating professionally. Also expected, with the presence of Islamic Bank as Nazhir, the level of public trust in Nazhir will also increase rapidly.

Based on the solutions outlined above, this study recommends strategies that can be done to optimize cash waqf management in Indonesia.

To optimize socialization of cash waqf, coordination and synergy between various stakeholders (stakeholders) are needed, both from regulatory elements, such as BWI and the Ministry of Religion's Waqf Empowerment Directorate, managers, that are, Nazhirs and academics to be involved in the socialization program comprehensively, both short term and long term. With the coordination, the stakeholders can take action in the same direction, so as to optimize the synergy that is built between all parties.

In the future, regulations need to be made to support the acceleration of the development of cash waqf in Indonesia, with the aim of optimizing the role of BWI, including with the discourse to make BWI as the main waqif, as mentioned above. Likewise, regulations should be in favor of the interests of optimizing sufficient funds for the development of cash waqf.

Related to Nazir's professionalism, regulations must also be made to make it easier for Islamic banks to become a nazhir of cash waqf, because as mentioned above, by making Islamic banks as the endowments, management of waqf assets can run optimally.

In enhancing Nazhir's professionalism, a continuous and 
planned effort to be able to improve the quality of the existing nazhirs is needed, as well as to produce young nazhir who are professional and have a good work ethic. All of this can work if there are good synergies between regulators, stakeholders and academics.

Likewise, the strategies described above can only run optimally if all parties contained in them can work together well, and various solutions and strategies offered run in parallel and comprehensively, because each other is interconnected. As can be seen in figure 1, where both socialization, regulations and nazhir are mutually related.

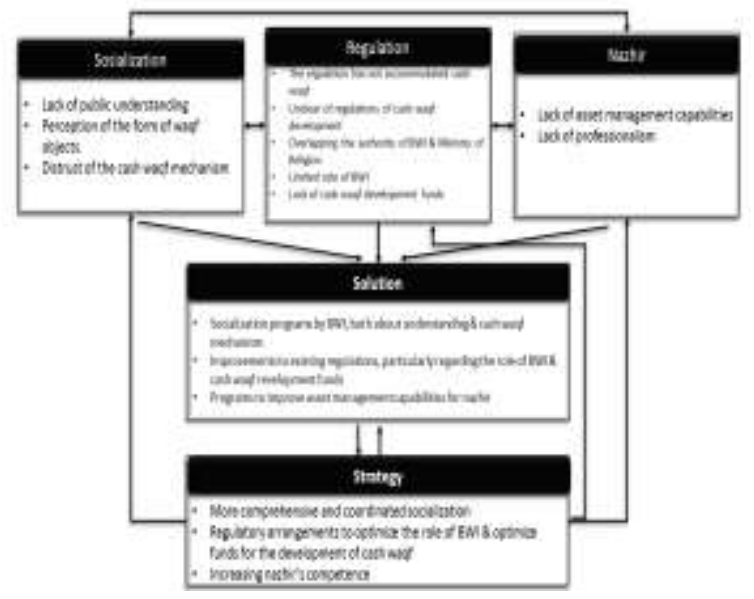

Figure 1. Strategy for Optimizing Cash Waqf Management in Indonesia

\section{CONCLUSION AND IMPLICATIONS}

Based on the discussion in the previous section, conclusions were obtained in an effort to optimize cash waqf, that are, first, in the effort to socialize cash waqf, there were several constraints, such as a lack of public understanding of cash waqf, public perceptions of cash waqf, and mistrust of the mechanism. To overcome this, socialization programs can be carried out by BWI and stakeholders in managing other cash waqf, both on understanding and the cash waqf mechanism. It is hoped that in the future people will become more familiar with cash waqf. Of course, socialization should run comprehensively and coordinated among all stakeholders in the practice of cash waqf, going in the same direction so that optimization can be achieved.

For this reason, in addition to conducting a socialization strategy in accordance with the necessity of modern era, it is also necessary to carry out simultaneous efforts to increase Muslim belief in Indonesia about the benefits of philanthropy, especially waqf, so that the Muslim community in Indonesia truly believes that by representing the property does not decrease from the side of Allah, in addition it is also necessary to echo good stories about waqf, so that the community will increase their enthusiasm to represent.

Secondly, regarding regulations, there are fundamental obstacles, namely the Act of the Republic of Indonesia No. 41 of 2004 concerning Waqf has not accommodated the practice of cash waqf in Indonesia, thus affecting conditions where the regulation of cash waqf development is still unclear, overlapping authority between BWI and the Ministry of Religion, Waqf Empowerment Directorate, limited role of BWI and due to inadequate regulations. Cash waqf development funds are less, so the process of optimizing cash waqf is still difficult. The solution offered is to improve existing regulations, especially the Act of the Republic of Indonesia No. 41 of 2004 concerning Waqf, specifically here is about BWI's role and about cash waqf development funds. 
In some countries, such as Turkey and Egypt, adopted the main nazir system, in which an institution acts as the main nazhir who oversees Nazhir in the entire country, where Nazhir-Nazir are Nazhir partners. Nazhir parent has great authority over all the representative activities in the country, such as receiving waqf assets handed over by wakif throughout the country and appointing Nazhir who will manage them, overseeing Nazhir's activities and accountability, as well as providing guidance, managing abandoned waqf assets, including appoint substitute Nazar if there is Nazhir who does not carry out his mandate properly.

The main nazhir system, if implemented in Indonesia, will be able to solve a number of problems, namely the problem of overlapping tasks between BWI and the Ministry of Religion's Waqf Empowerment Directorate, the problem of limited BWI space and budget problems for BWI.

Third, related to Nazhir, the obstacle faced is Nazhir's professionalism in which the ability to manage waqf assets is still minimal, so programs are needed to improve asset management capabilities for Nazhir, both training and certification programs, and making Islamic banks as Nazir cash endowments. Likewise, the strategy for the long term is with a continuous program to be able to improve Nazhir's competence so that it can carry out its duties with full trust.

Waqf in Indonesia needs Nazhir who is skilled in fund mobilization activities, while understanding aspects of Sharia in managing financial assets. These competencies can actually be fulfilled by Islamic banks, if the law provides space for Islamic banks to become special nazhir for cash waqf.

\section{REFERENCE}

Ab Rahman, A. (2009). Peranan wakaf dalam pembangunan ekonomi umat Islam dan aplikasinya di Malaysia. Shariah Journal, 17(1), 113-152.

Adeyemi, A. A., Ismail, N. A., \& Hassan, S. S. B. (2016). An Empirical Investigation of the Determinants of Cash Waqf Awareness in Malaysia. Intellectual Discourse, 24(0).

Dahlan, R. (2015). Faktor-faktor Yang Memengaruhi Persepsi Nazhir Terhadap Wakaf Uang. Al-Iqtishad: Jurnal Ilmu Ekonomi Syariah, 6(2), 305-315.

Fanani, M. (2011). Pengelolaan Wakaf Tunai. Walisongo: Jurnal Penelitian Sosial Keagamaan, 19(1), 179-196.

Furqon, A. (2011). Analisis Praktek Perwakafan Uang pada Lembaga Keuangan Syariah. Walisongo: Jurnal Penelitian Sosial Keagamaan, 19(1), 157-178.

Huda, N., Anggraini, D., Rini, N., Hudori, K., \& Mardoni, Y. (2014). Akuntabilitas Sebagai Solusi Pengelolaan Wakaf. Jurnal Akuntansi Multiparadigma, 5(3), 485.

Huda, N., Rini, N., Mardoni, Y., Anggraini, D., \& Hudori, K. (2017). Manajemen Pengelolaan Wakaf di Indonesia Timur. EKUITAS (Jurnal Ekonomi dan Keuangan), 20(1), 1-17.

Ilyas, S. (2014). Perkembangan Perwakafan di Kota Batam. Jurnal Bimas Islam, 7(4), 783-795.

Indonesia, \& Direktorat Pemberdayaan Wakaf. (2007). Pedoman pengelolaan wakaf tunai. Jakarta: 
Direktorat Pemberdayaan Wakaf, Direktorat Jenderal Bimbingan Masyarakat Islam.

Md Saad, N., Kassim, S., \& Hamid, Z. (2013). Involment of Corporate Entities in Waqaf Management: Experiences of Malaysia and Singapore. ResearchGate.

Moleong, L. J. (2007). Metodologi Penelitian Kualitatif. Bandung: Remaja Rosda Karya.

Muntaqo, F. (2015). Problematika dan Prospek Wakaf Produktif di Indonesia. Al-Ahkam, 1(25), 83-108.

Nugroho, S. A., \& Fahmi, A. (2013). Aplikasi Sistem Informasi Geofrafis e-Wakaf Sebagai Tool Pengelolaan Aset Wakaf pada Kantor Kementerian Agama Kota Surakarta. Techno.Com, 12(2), 82-89.

Prihatini, F., Hasanah, U., \& Wirdyaningsih, 1970-. (2005).
Hukum Islam: zakat dan wakaf: teori dan prakteknya di Indonesia / Farida Prihatini, Uswatun Hasanah, Wirdyaningsih. Jakarta: Diterbitkan atas kerjasama Papas Sinar Sinanti dengan Badan Penerbit Fakultas Hukum Universitas Indonesia.

Saaty, T. L. (2005). Theory and Applications of the Analytic Network Process: Decision Making with Benefits, Opportunities, Costs, and Risks (3 edition). Pittsburgh: RWS Publications.

Saaty, T. L., \& Vargas, L. G. (2013). Decision Making with the Analytic Network Process (2nd ed.). Springer US.

Trochim, W., Donnelly, J. P., \& Arora, K. (2015). Research Methods: The Essential Knowledge Base (2 edition). Boston, MA: Wadsworth Publishing 